\title{
Elżbieta Wołodźko
}

Uniwersytet Warmińsko-Mazurski w Olsztynie

\section{Autonomia w przestrzeni akademickiej -znaczenia, doświadczenia, ograniczenia}

\section{Wprowadzenie}

W debacie na temat autonomii współczesnego człowieka obecny jest spór między zwolennikami jej oświeceniowego rozumienia (Kant, Fichte, Hegel) obrazującego podmiot jako „antropologicznego olbrzyma” (Kruszelnicki, 2008, s. 15-26) a przedstawicielami egzystencjalizmu, transgresjonizmu i postmodernizmu, którzy ogłosili śmierć podmiotu i rozmycie jego autonomii. Ci pierwsi obdarzają jednostkę „poczuciem pełnego sprawstwa w dziedzinie własnej egzystencji” (Kruszelnicki, 2008, s. 17), jednością osoby („sobości”) z podejmowanym przez nią działaniem oraz wewnątrzsterownością osoby „kroczącej dumnie droga światłej edukacji ku pełnej samorealizacji” (Kruszelnicki, 2008, s. 17). Drudzy we współczesnym człowieku dostrzegają konsumenta i niewolnika „administracyjnej machiny nowoczesnego społeczeństwa" (Męczkowska, 2006) zawłaszczającej wolność i autonomię jednostki uwikłanej w relacje władzy i ograniczanej w swoich możliwościach decyzyjnych i sprawczych (Foucault, Bauman, postmoderniści).

Także inni humaniści - zwłaszcza biologiczni redukcjoniści i kulturowi relatywiści podają w wątpliwość „realność i znaczenie konstruktu autonomii oraz blisko związanych z nim pojęć, jak wola, osobisty wybór czy postanowienie" (Ryan, 2006, s. 1559), krytykując ich iluzoryczność i oderwanie od kontekstu kulturowego i społecznego. Badacze ci dostrzegają zatem uwikłanie współczesnego człowieka w pozbawiające go autonomii praktyki uczestnictwa w instytucjach życia społecznego (Melosik, 2013; Pieniążek, 2008, s. 39-50), zwracając przy tym uwagę na osobotwórcze (paradoksalnie) działanie presji wywołującej w jednostce gotowość do obrony osobistych racji, przekonań, stylu życia, samodzielnie definiowanych wartości (Kopka, 2008). Proces stawania się osobą autonomiczną oznacza zatem doświadczaną przez jednostkę konieczność negocjowania zakresu autonomii w toku wielu różnorodnych doświadczeń społecznych, obszarów działalności, w jakich jest osiągana „autonomia w życiu” (Christman, Anderson, 2005; Haworth, 1986), autonomia osób uczących się (Benson, 2008, 2013), sfer rozwoju (moralnego, poznawczego, psychospołecznego), w jakich następuje jej urzeczywistnianie, co wiąże się z rozwiązywa- 
niem życiowych zadań, pokonywaniem rozwojowych kolizji i kryzysów ${ }^{1}$. Ten rozwojowy proces dokonuje się poprzez „rzeczywiste” podejmowanie autonomicznego (niezależnego, odpowiedzialnego, twórczego, zanurzonego w społecznych relacjach) myślenia i działania. Jest to swoisty „paradoks autonomii” - jednostka staje się autonomiczna w toku autonomicznego działania, wówczas gdy realizuje wybrane przez siebie wartości, normy, cele, wkładając w to często duży wysiłek związany z koniecznością osobowej i społecznej transgresji (Little, Ridley, Ushioda, 2003).

Wśród badaczy sprzeciwiających się pesymistycznej wizji „śmiertelnego" uwikłania podmiotu znajdują się także filozofowie i socjologowie edukacji (Kwieciński, 2014; Melosik, 2013; Nussbaum, 2008ab) oraz pedagodzy (zwłaszcza szkoły wyższej - Ciechanowska, 2015; Czerepaniak-Walczak, 2013; Gołębniak, 2008ab, 2010), którzy postulują rewitalizację podmiotowości i autonomii jednostki poprzez edukację podejmowaną „w obronie człowieczeństwa" (Aviram, 2010; Nussbaum, 2008b), zorientowaną na osobowy rozwój, Sokratejską ideę namysłu nad sobą i życiem oraz Arystotelesowskie rozumienie obywatela refleksyjnego (Nussbaum, 2008ab). Te silnie artykułowane głosy zawierają protest przeciw zmianom następującym w sposobie funkcjonowania instytucji edukacyjnych podporządkowanych neoliberalnej ideologii, korporacyjnemu myśleniu, merkantylizacji uniwersytetu oraz utraty jego autonomii i możliwości realizowania funkcji kulturowych i wychowawczych (Bauman, 2008; Melosik, 2008). Pedagodzy ci wskazują na ograniczenia autonomii instytucjonalnej oraz autonomii podmiotów edukacyjnych, które tkwią w sposobie funkcjonowania edukacji wyższej poddanej neoliberalnej presji, odhumanizowanej, korporacyjnej (Czerepaniak-Walczak, 2013; Potulicka, Rutkowiak, 2012). Niektórzy z nich (Szostek, 2017; Sztompka, 2017) dostrzegają istotne zagrożenia związane z inwazją innych kultur na kulturę akademicką, której autonomia - politycznie, instytucjonalnie i osobowo rozumiana jest fundamentem niezależnego funkcjonowania uniwersytetu w społeczeństwie.

\section{Kontrowersje wokół definicji autonomii}

W bogatej literaturze obejmującej wiele dyskursów autonomii pojęcie to definiowane jest niejednoznacznie, wskazuje się wiele jego konotacji, przestrzeni doświadczania i rozumienia. Badacze autonomii coraz bardziej skłaniają się jednak do przyznawania, że jest ona raczej „,intrapsychicznym procesem” (Boykin McElhaney, Allen, 2001; Lynch, Vansteenkiste, Deci, Ryan, 2011) niż stabilnym stanem psychiki (Koczanowicz, 2005, s. 88), „statycznym produktem” (Thanasoulas, 2006); jest zmienna, niestabilna, „uzależniona” od wielu kontekstów jej doświadczania. Oznacza osobową możliwość definiowania własnych znaczeń i rozwijania ich „w toku procesu negocjacji i mediacji, w atmosferze prawdziwe-

1 Te rozwojowe aspekty autonomii przedstawiają twórcy znanych powszechnie teorii rozwoju: Jean Piaget, Lawrence Kohlberg, Erik Erikson, Lew Wygotski, James Marcia, Robert Havighurst. 
go dialogu i kolegialności (collegiality)" (Huang, 2006). W proces kształtowania autonomii wpisane jest zatem wzajemne przenikanie się czynników osobowych i kontekstualnych, z uwzględnieniem dynamiki (zmienności, wzbogacania) oddziaływań zarówno jednych, jak i drugich. Istotną cechą autonomii jest jej wielowymiarowośćn ${ }^{2}$ która obrazuje trudność uchwycenia wszystkich jej przejawów, dynamikę rozwoju, osobową i kontekstualną unikalność potwierdzającą konieczność badawczego dokonywania operacjonalizacji tego pojęcia. Nawet w obrębie nauk, w których autonomia stanowi znaczący przedmiot badań, nie ma zgodności co do sposobu jej ujmowania. Na przykład w dyskursie psychologicznym autonomia traktowana jest jako niezależność (Obuchowski, 2000; 2006), self-determination (Ryan, Deci, 2006), samoświadomość, samourzeczywistnienie (Rogers, 2002), indywiduacja (Łapiński, 1988), transgresja (Kozielecki, 2001), dojrzałość (Dąbrowski, 1988), ale także dystans i separacja (Beyers, Goossens, Vasant, Moors, 2003; Dołęga, 2000). Wśród znaczeń nadawanych autonomii przez filozofów odnajdziemy m.in. wolną wolę (Kant, Fichte, Hegel) (Banasiak, 2008; Kruszelnicki, 2008), refleksyjność (Gezerlis, 2001), samostanowienie (Perkowski, 2001), autentyczność i zdolność kierowania sobą (Mill, 1959). Pedagodzy, którzy zajmowali się „uwolnieniem” podmiotowości ucznia, wskazywali na jego upełnomocnienie (Czerepaniak-Walczak, 2006; Pestalozzi, 1972), odpowiedzialność (Dam, 1995; Holec, 1981; Little, 1991), podkreślali konieczność jej uzyskiwania jako centralnej wartości życiowej (Dykcik, 2009).

Znaczącym aspektem rozumienia pojęcia autonomii są charakteryzujące ją ambiwalencje. Oznacza to, że jednostka dążąca ku autonomii doświadcza wielu napięć „skazujących" ją niejednokrotnie na przeciwstawne dążenia w poszukiwaniu właściwego dla siebie sposobu doświadczania siebie jako osoby autonomicznej. Nierzadko są to konflikty wewnętrzne, jakie przeżywa jednostka $\mathrm{w}$ drodze ku autonomii, starając się uzyskać harmonię między przynależnością i niezależnością; samodzielnością i współpracującym uczestnictwem; aktywnością i wycofaniem; potrzebą akceptacji zewnętrznej i potrzebą samoakceptacji; potrzebą bezpieczeństwa i potrzebą ponoszenia ryzyka i testowania swoich możliwości; potrzebą więzi i potrzebą dystansowania się od grupy (Speck, 2005, s. 157-158). Jest to swoisty stan disequilibrium doświadczany przez jednostkę balansującą z jednej strony między potrzebą kierowania sobą, sprawstwa, zdolności do nawiązywania relacji, współzależności w społecznych interakcjach (Autonomia 1), z drugiej zaś dążącą ku niezależności, społecznego dystansu, a nawet izolacji (Autonomia 2) (Hmel, Pincus, 2002, s. 278). Autonomia wyraża zatem dążenie jednostki do realizowania określonych osobiście wartości i celów w toku (względnie) niezależnego (od zewnętrznych norm i ograniczeń przepisów roli), kierowanego samodzielnie działania jako szansy na ujawnienie w pełni i twórczo własnej osobowości (Labouvie-Vief, 1982).

2 Według metodyków języków obcych autonomia jest wielowymiarowym konstruktem, proces jej rozwoju wiąże się $\mathrm{z}$ uczestnictwem $\mathrm{w}$ zadaniach edukacyjnych rozwijających psychologiczne dyspozycje jednostki (zob. np. Benson, 2013, s. 51). 
W edukacyjnym dyskursie autonomii wiele miejsca zajmują zagadnienia dotyczące trudności spotykanych przez nauczycieli (akademickich) i studentów w podejmowaniu praktyk autonomicznego uczenia się/studiowania (Palfreyman, Smith, 2003) oraz w tworzeniu edukacyjnej przestrzeni sprzyjającej rozwijaniu autonomii uczestników procesu edukacyjnego - autonomy supportive environment (Benson, za: Huang, 2006, s. 39). Z badań tych wynika, że większość nauczycieli akceptuje ideę autonomizacji edukacji, ale wprowadzanie autonomii w swojej praktyce profesjonalnej uznają za zadanie trudne i obarczone wieloma ograniczeniami (Benson, Voller, 2014).

\section{Refleksyjny proces badawczy}

W artykule przedstawiono fragment projektu badawczego zainspirowanego moimi wcześniejszymi badaniami. Były to edukacyjne badania w działaniu prowadzące uczestniczących w nich studentów - w toku edukacyjno-badawczego procesu - „ku autonomii studiowania" (Wołodźko, 2013). Podczas realizacji wielu edukacyjnych działań podejmowanych w powstającej edukacyjnej wspólnocie i poddawanych zróżnicowanej refleksji studenci doświadczali autonomicznego studiowania, nadając im swoje znaczenia. „Działaniowo” konstytuowali rozumienie autonomii konfrontowane z wcześniejszymi praktykami uczenia się, utrwalanymi w toku rodzinnej i szkolnej socjalizacji w różnorodnych edukacyjnych środowiskach (instytucjach). Ujawnionych zostało wówczas wiele ograniczeń autonomii doświadczanych przez studentów (i nauczyciela-badacza), o różnym charakterze, umiejscowieniu, sile oddziaływania. W zakończeniu tekstu stanowiącego raport z tych badań wyraziłam zatem potrzebę kontynuacji poszukiwań badawczych zarówno po to, by takie ograniczenia „głębiej” zidentyfikować, jak i po to, by (znów), uruchamiając procesualny i refleksyjny proces badawczy action research (tym razem z udziałem większej grupy nauczycieli akademickich i studentów), podjąć próbę ich przezwyciężania w edukacyjno-badawczej przestrzeni rodzimego uniwersytetu. Ostatecznie, wobec różnych organizacyjnych trudności, badań tych nie udało się do końca zrealizować, zostały zatem włączone $\mathrm{w}$ inny, szerszy projekt badawczy action research, który aktualnie jest zespołowo opracowywany.

Prezentowana część badań dotyczyła pierwszego etapu badań w działaniu, jakim jest - według Susmana i Evereda (2010, s. 89-117) - dokonanie diagnozy sytuacji „wejściowej" (input), co wiąże się ze zgromadzeniem danych niezbędnych do zakreślenia pola badawczego, a w szczególności doprecyzowania początkowo formułowanych problemów badawczych. Jest to związane z jakościowym spiralnym procesem badawczym action research, umożliwiającym badaczowi i uczestnikom badań dokonywanie zmian $\mathrm{w}$ procedurze badawczej, podyktowanych refleksją nad wcześniejszymi działaniami, refleksjami $i$ ich skutkami. Badania w działaniu mają bowiem refleksyjny i narracyjny charakter (Colombo, 2003), łączą myśli i działania, których następstwa także poddane są refleksji, a ta 
$\mathrm{z}$ kolei włączana jest do przedmiotu badań. Wielu metodologów action research (Bradbury, 2015; Červinková, Gołębniak, 2010; 2013; Czerepaniak-Walczak, 2001ab; Kemmis, McTaggart, 2005; Reason, Bradbury, 2005; Reason, Torbet, 2010) podkreśla znaczenie refleksyjności rozwijanej przez uczestników tych interwencyjnych badań. Jest ona doświadczana we wszystkich etapach, począwszy od diagnozowania, poprzez planowanie i podjęcie działania, jego ewaluację oraz „specyfikację procesu uczenia się” (Susman, Evered, 2010, s. 97). Refleksyjność przenika obszary jednostkowego i społecznego uczestnictwa, staje się dynamizmem rozwoju osobowego (autorefleksja), przenika procesy budowania relacji (refleksja wspólnotowa - communal) i procesy współpracy (refleksja towarzysząca współpracy - collaborative; Feldman, 2001). Towarzyszy także działaniom prowadzącym do rozwiązywania wspólnie zdefiniowanego problemu oraz przenika proces badawczy dotyczący monitorowania „dziania się" wielu zachodzących w badawczej wspólnocie procesów (poznawczych, motywacyjnych, refleksyjnych, społecznych, rozwojowych, epistemicznych). Ich dynamizm i wzajemne interakcje tworzą specyficzną dla action research przestrzeń wzajemnego uczenia się opartego na indywidualnym i społecznym doświadczaniu, otwartości na zróżnicowane sposoby nadawania znaczeń, osobowej ekspresji, pogłębianej refleksyjności. Taki sposób realizacji badań partycypacyjnych stanowi rodzaj refleksyjnej edukacji, przy czym refleksja jest nie tylko narzędziem poznania, lecz także narzędziem zmiany: myślenia i wynikającego z niego działania, które również poddane jest refleksyjnej ocenie prowadzącej do uogólniającej i epistemicznej (teoriotwórczej) refleksji i metarefleksji (Susman, Evered, 2010, s. 97).

Pytania, które wyznaczyły zamierzenia badawcze, były następujące: W jaki sposób studenci i nauczyciele akademiccy identyfikują ograniczenia ich akademickiej autonomii oraz w jaki sposób tych ograniczeń doświadczają? Jakie działania chcieliby podjąć, żeby te ograniczenia pokonywać?

Chcąc zebrać refleksyjny, związany z szerokim opisem edukacyjnych doświadczeń studentów materiał badawczy, posłużyłam się techniką refleksyjnego pisania (reflective writing) (Jasper, 2005, s. 247-260). Opracowałam "pisemne” narzędzie badawcze, którym był zbiór otwartych pytań skłaniających osoby badane do refleksyjnych i szeroko formułowanych odpowiedzi. Badanie było anonimowe, studenci mogli zatem wypowiadać się swobodnie, mieli także czas do namysłu i możliwość sformułowania przemyślanych wypowiedzi. W tej części badań uczestniczyli studenci studiów licencjackich (II roku pedagogiki opiekuńczej).

Dzięki tak zgromadzonym danym (w badaniach brali udział wszyscy studenci „kursowi” danej specjalności) i poddaniu ich jakościowej analizie, spodziewałam się zrekonstruować znaczenia nadawane autonomii, jej doświadczaniu, poznać ograniczenia badanego fenomenu, w sposób "nasycony” i znacznie mniej czasochłonny niż poprzez przeprowadzanie wywiadów. Już jednak w toku wstępnej analizy tego materiału badawczego okazało się, że większość studentów na postawione pytania odpowiadała zwięźle, jakby pośpiesznie, najczęściej jednym zdaniem - pełne, refleksyjne wypowiedzi były rzadkie. Niektóre pyta- 
nia zostały pominięte, a wśród nich najczęściej kwestia ograniczeń autonomii dostrzeganych w życiu obywatela i studenta. Zebrany materiał empiryczny nie był zatem tak bogaty, jak się spodziewałam. To spostrzeżenie skłoniło mnie do poszukiwania dodatkowych możliwości zgromadzenia danych. Przeprowadziłam więc otwarte, pogłębione wywiady ze studentami, których wybrałam spośród wolontariuszy z wydziałowej świetlicy terapeutycznej, członków kół naukowych czy samorządu studenckiego. Celowo szukałam bowiem osób, których doświadczenia edukacyjne są bogate i refleksja z nimi związana wykracza poza schematyczne rejestrowanie przebiegu procesu edukacyjnego. Wywiadów tych udzieliło mi siedmioro studentów (w tym jedna studentka studiów doktoranckich). Były to trwające przeważnie godzinę wyczerpujące opowieści o ich sposobach rozumienia autonomii, tego, co jej sprzyja i nie sprzyja, i zmianach, jakie w przestrzeni edukacyjnej chcieliby wprowadzać. Odniosłam wrażenie, że uczestnictwo w naszych rozmowach było dla tych studentów okazją do pogłębionej refleksji nad studiowaniem, doświadczeniem stawania się osobą autonomiczną w wielu edukacyjnych przestrzeniach. Wywiady otwarte przeprowadziłam także z czterema nauczycielami akademickimi, mając świadomość konieczności kontynuowania tych badań i ostrożnego podejścia do rekonstruowania badanego fenomenu w świetle niewystarczającego jeszcze materiału badawczego, ukazującego jednak pewne interesujące tendencje w myśleniu i działaniu (opowiedzianym) przez tę grupę badanych.

\section{Analiza i rekonstrukcja danych}

Zastosowanie dwóch różnych narzędzi gromadzenia danych, w moim zamierzeniu obydwu sprzyjających pogłębionej refleksji osób badanych, spowodowało jednak uzyskanie zróżnicowanego materiału badawczego. Narzędzie pisemne (reflective writing) - mimo zawartych w nim otwartych i skłaniających do refleksyjnych wypowiedzi pytan - nie stanowiło dla studentów wystarczającej zachęty do namysłu, do bardziej rozbudowanych i osobistych rozważań. Sądzę też, że udzielenie odpowiedzi na otwarte, wymagające szerszego omówienia nieznanych zagadnień pytania było dla studentów II roku zadaniem trudnym. Niektórzy z nich „ratowali się" szukaniem odpowiedzi w Internecie, wykorzystując telefony komórkowe, stąd część z tych wypowiedzi przypominała raczej definicje spotykane $\mathrm{w}$ literaturze niż osobiście sformułowane refleksje. $\mathrm{Z}$ kolei zastosowanie pogłębionego wywiadu otwartego z grupą studentów starszych, z większym też doświadczeniem studiowania, umożliwiło zebranie materiału refleksyjnego, narracyjnego, ukazującego ich namysł i autorefleksję.

Analizując wypowiedzi studentów II roku, dostrzegłam w nich określone różnice i na ich podstawie wyodrębniłam dwie grupy badanych, nazywając jednych z nich studentami „rozczarowanymi”, drugich "roszczeniowymi”. Dokonanie takiego podziału wiązało się z charakterem uzyskanych wypowiedzi. Studenci „rozczarowani” to ci, którzy wska- 
zywali przede wszystkim na ograniczenia ich autonomii w drodze ku zaangażowanemu studiowaniu, zdobywaniu profesjonalnej wiedzy i umiejętności, rozwojowi zainteresowań i zdolności. Z ich wypowiedzi wynikało niezadowolenie z powodu doświadczanych przeszkód w przygotowywaniu się do zawodu, który wybrali celowo, dążąc do zostania pedagogiem. Studenci "roszczeniowi” to natomiast ci, którzy zwracali uwagę przede wszystkim na to, żeby przejść przez studia z jak najmniejszym wysiłkiem, ich wypowiedzi dotyczyły głównie wymagań związanych z korzystną dla nich organizacją zajęć, ułatwieniami i usuwaniem przeszkód, tak by studiowanie ich zbytnio nie zmęczyło.

Wszyscy badani - włącznie z nauczycielami akademickimi - wskazali na cztery „obszary” doświadczanych ograniczeń autonomii. Pierwszy z nich określiłam jako „czynnik ludzki" - dotyczył bowiem osób uczestniczących w edukacji akademickiej. Drugi odnosił się do organizacji procesu edukacyjnego, trzeci określał sposób postrzegania systemu edukacji wyższej jako bariery w doświadczaniu autonomii (osobowej i instytucjonalnej). Obszar czwarty obejmował propozycje działań, jakich wprowadzenie postulowali uczestnicy badań w celu przeciwdziałania ograniczeniom autonomii podmiotów edukacji wyższej.

Analiza danych dotyczących osób - uczestników procesu edukacyjnego w szkole wyższej wskazała na wzajemne postrzeganie siebie (nauczycieli akademickich i studentów) jako ograniczeń w pełnym korzystaniu przez nich z autonomii w toku pracy i studiowania. Nauczyciele stwierdzali:

Choćbym miał nie wiadomo jakie szczytne cele, to jeśli w grupie będą osoby o niższych kompetencjach (...) to te wymyślone przeze mnie rzeczy nie będą możliwe do zrealizowania (nauczyciel akademicki, mężczyzna).

Moją autonomię związaną z wolnością pracy nauczyciela akademickiego ograniczają studenci. Niestety obecny sposób rekrutacji powoduje niejednokrotnie negatywną selekcję do zawodu pedagoga. Są to studia w przekonaniu wielu osób łatwe, bez matematyki i innych trudnych przedmiotów, więc przychodzą do nas osoby słabe (nauczyciel akademicki, kobieta).

Ograniczeniem autonomii według nauczycieli akademickich są też inne osoby - przełożeni i współpracownicy. Jednym zarzucali brak opieki naukowej, drugim brak możliwości naukowej komunikacji, dyskusji, brak pracy zespołowej.

Studenci "rozczarowani” jako ograniczenia związane z "czynnikiem ludzkim” wskazywali na nauczycieli pozbawiających ich swobody wypowiadania się, "uśrednianie” wymagań, brak indywidualnego podejścia do uczących się osób, tradycyjny sposób przekazu wiedzy. Pisali:

Nie można mówić swojego zdania (studentka, II rok).

Nauczyciele traktują nas jak „szarą masę”, a jesteśmy różni (studentka, II rok).

Na zajęciach przepisujemy slajdy, zamiast dyskutować czy rozmawiać w grupie z nauczycielami (studentka, II rok).

Nie mamy wpływu na wybór tematyki zajęć (studentka, II rok). 
Z kolei studenci „roszczeniowi” zarzucali nauczycielom „konieczność obowiązkowej obecności na ćwiczeniach, jak również na wykładach, pisanie egzaminów w terminie ustalonym przez wykładowców, konieczność odbywania praktyk w okresie wakacyjnym" (studentka, II rok).

Studenci starsi także wyrażali niezadowolenie z powodu braku możliwości wypowiedzenia swojego głosu, oczekiwali przy tym od nauczycieli akademickich organizowania działań twórczych związanych ze zdobywaniem doświadczeń pozauczelnianych:

Nauczyciel mówi, że oczekuje naszego zdania lub napisania pracy z własnymi poglądami, a ocenia nas pod kątem własnych poglądów (studentka, $\mathrm{V}$ rok).

Można przeciwstawić tych wykładowców, którzy nas rozwijają, do tych, którzy nas cały czas karcą za coś, ganią za coś, którzy przekazują co nas interesuje mniej, że musimy czasem napisać suche prace. A ja bym wolała napisać pracę, że muszę gdzieś pójść, czegoś doświadczyć (studentka, V rok).

Jedna ze studentek wskazała na brak zaangażowania samych studentów, ale dodała też sugestię stanowiącą usprawiedliwienie bierności swoich kolegów. Powiedziała:

Wydaje mi się, że barierą jest taka niechęć do robienia czegoś, brak motywacji do zajęcia się czymś, cokolwiek, żeby robić coś z czasem swoim. Może też brak informacji o tym, co mogłoby ich zainteresować, bo ja o tym wolontariacie dowiedziałam się przypadkowo (studentka, $\mathrm{V}$ rok).

Obie strony zatem, zarówno nauczyciele akademiccy, jak i studenci, postrzegały siebie nawzajem jako ograniczenie autonomii, przy czym tylko przedstawicielka starszych studentów podjęła pewną krytyczną refleksję dotyczącą braku de facto autonomii studentów, którzy nie angażują się w studiowanie i nie poszukują korzystnych dla siebie możliwości takiego zaangażowania.

Duża część wypowiedzi osób badanych dotyczyła procesu edukacyjnego i jego organizacji. Studenci „rozczarowani” narzekali na lekceważenie ich potrzeb edukacyjnych związanych $\mathrm{z}$ autonomią, twórczością, brakiem przestrzeni na samodzielność ich myślenia i działania, na tradycyjne metody nauczania stosowane przez nauczycieli.

Często jest tak, że najlepsze oceny mają ci, którzy wkuwają na pamięć to, co było na wykładach na slajdach, a jeśli ktoś coś od siebie dodaje, to już gorzej (studentka, II rok).

Nauczyciele powszechnie stosują testy, które ogłupiają zamiast uczyć swojego sposobu myślenia (studentka, II rok).

Niektórzy z nich przejmują inicjatywę na nudnych zajęciach: „Często prowokuję burzliwe dyskusje, które w gruncie rzeczy wzbogacają moją wiedzę, a czasem zmieniają mój pogląd na określone kwestie" (studentka, II rok).

Studenci „rozczarowani” postulowali też zwiększenie oferty przedmiotów do wyboru, z uwzględnieniem ich zainteresowań, a także więcej zajęć praktycznych. Twierdzili również, że doświadczają utrudnień dotyczących studiowania drugiego kierunku.

Studenci „roszczeniowi” protestowali przeciw pomijaniu ich głosu w organizacji, planowaniu procesu edukacyjnego, a zwłaszcza przeciw konieczności terminowego zda- 
wania egzaminów, niskim stypendiom, obowiązkowym wykładom, liczbie godzin zajęć. Postulowali ograniczenie liczby „przedmiotów niepotrzebnych”. Częściej niż pozostali studenci pisali także o złych w ich ocenie warunkach studiowania, jak „brzydki budynek”, „słabe wyposażenie sal wykładowych”, „brak wydziałowej biblioteki”. Oczekiwali również „zmniejszenia formalności dotyczących obsługi studenta” oraz „większego szacunku do studenta ze strony dziekanatu (personelu)".

$\mathrm{Na}$ niedostatki dotyczące warunków pracy wskazywali też badani nauczyciele. W ich ocenie najbardziej dokuczliwy okazał się brak wystarczającej liczby pokoi i związana z tym „ciasnota”. Krytykowali także „zbyt duże grupy studenckie, co utrudnia prowadzenie warsztatów i innych zajęć aktywizujących". Inaczej ograniczenia te postrzegała studentka studiów doktoranckich (początkujący nauczyciel akademicki):

Dla mnie najtrudniejszy jest brak czasu na refleksję, gdy dostajemy tak dużo głosów z zewnątrz, to można się zagubić. A pracy nauczyciela akademickiego sprzyja czas na to, żeby się spotkać, wspólna przestrzeń.

O potrzebie współuczestnictwa i współdecydowania mówili też studenci starsi, którzy do swoich nauczycieli kierowali konkretne propozycje doskonalenia procesu edukacyjnego.

Myślę, że dobre byłoby spotkanie, że i my będziemy rozumieli tę drugą stronę, a ta druga strona będzie rozumiała nas, że to będzie taki czas akurat właśnie po to i będzie potrzebny, żeby powiedzieć też o naszych potrzebach i powiedzieć, czego my byśmy się spodziewali (studentka, V rok).

Wskazywali też na tę przestrzeń nauczycielskiego działania, która w ich ocenie wiąże się z możliwością pokonywania ograniczeń autonomii studentów. „Budowanie motywacji, pracowanie nad motywacją, nad potrzebami studentów, bo też czasem te potrzeby są takie, aby czasem wpisać tróję i starczy" (studentka, V rok, wolontariuszka w świetlicy terapeutycznej). I wskazywali, jakie konkretnie działania kształtowaniu takiej motywacji sprzyjają: „Wydaje mi się, że taką pierwszą rzeczą byłoby robienie projektów, grupowe, gdzie musimy z czymś wyjść, zobaczyć coś, zbadać, z czymś się zapoznać, czegoś sami doświadczyć" (studentka, V rok, wolontariuszka w świetlicy terapeutycznej).

Ograniczenia autonomii odnoszone były także do systemu edukacji wyższej. Nauczyciele dostrzegali konieczność podporządkowania się wymogom funkcjonowania w systemie („byłaby anarchia”, „nie jestem rewolucjonistą”) oraz regułom awansu (,inaczej mnie nie zaakceptują"), ale też twierdzili, że „jeśli system ograniczy nas bardzo, będziemy musieli działać poza systemem, niejako na banicji”. Krytykowali konieczność dostosowania się do wymagań związanych z działalnością badawczą, do reguł, tematów, metodologii, interpretacji oczekiwanych przez naukowy „mainstream”. Wyrażali wiele obaw związanych z aktualnym kierunkiem zmian:

To jest też ciekawa sprawa, bo w obliczu przeliczania na punkty z tyłu głowy myślę, że tak naprawdę jesteśmy w ogromnej machinie i w systemie, który tak do końca nie pozwoli nam być autonomicznym. 
Dziękuję tylko za tę swobodę, autonomię, którą mogę mieć w relacji ze studentem (...), ale wiem, że na końcu muszę to przeliczyć i podsumować tak, jak ja będę podsumowana.

Ograniczenia systemowe studenci wiążą ze złą pracą „polityków, którzy rządzą w kraju”, krytykują „pozorną wolność, jaką ma obywatel, pozorny wpływ na decyzje dotyczące obywateli”. „System polityczny to narzędzie zniewolenia i tak jest też w edukacji” (student, II rok).

Zwrócili też uwagę na ograniczenia związane z dostępem do uczelni wyższych w małych miejscowościach, których mieszkańcy są w ich ocenie pozbawieni takich możliwości edukacyjnych, jak w dużych miastach.

Wobec wielu wskazanych przez badanych ograniczeń autonomii w przestrzeni edukacji wyższej zapytałam także o proponowane przez nich działania, dzięki którym ograniczenia te mogą być pokonywane. Dużą ostrożność w wypowiedziach na ten temat wykazali badani nauczyciele. Oto ich odpowiedzi:

Nie wiem, jakie działania.

Gdybym mógł decydować, to trzeba dużo ostrożności, odpowiedzialności, namysłu.

Warto dyskutować, rozmawiać.

Przecież reforma goni reformę i co z tego?

Wykazali się zatem niewiedzą lub biernością, brakiem zaangażowania w przełamywanie doświadczanych ograniczeń. Podobnie - mimo dużego zaangażowania w działalność wolontarialną - wypowiedziała się studentka V roku. Na pytanie, jakie działania podejmuje, gdy spotka się z ograniczeniami swojej autonomii na uczelni, odpowiedziała:

Żadne. Nauczycielom trzeba się podporządkować, bo to wiadomo, student też nie może się tak ujawniać, że tak się na pierwszy ogień rzucać, że on wie lepiej i tak ma być. Nie ma dialogu między nauczycielami a studentami, lęk studentów przed ujawnianiem ich oczekiwań. Czasami można wyrazić delikatnie jakieś swoje zdanie... To wymaga odwagi, bo czasami jest tak, że dobrze, porozmawiajmy o tym, ale... zależy od tej drugiej strony, jak ona do tego podchodzi, jak ona reaguje, jak narrację z nami prowadzi.

Pewne propozycje zgłosili studenci II roku. „Rozczarowani” postulowali „limitowanie przyjęć na studia i przywrócenie egzaminów wstępnych, żeby przywrócić poziom studiów wyższych; selekcję kadry nauczycielskiej oraz udogodnienia dla studentów pracujących". Studenci „roszczeniowi” rzadko odpowiadali na to pytanie lub pisali „więcej praktyk”, „większe stypendia dla potrzebujących”, „przedszkola dla dzieci studentek”.

\section{Refleksje badacza}

Przeprowadzone badania ujawniły, jak sądzę, pewne pola napięć związane z doświadczaniem ograniczeń autonomii przez podmioty edukacji wyższej. Badania dotyczyły małej 
grupy osób, nie zamierzam zatem formułować szeroko zarysowanych konstatacji, pewne tendencje charakteryzujące środowisko akademickie zostały jednak ujawnione.

Jest to przede wszystkim fakt sytuowania ograniczeń autonomii w partnerach procesu edukacyjnego, jakimi są studenci i nauczyciele. Zwraca uwagę negatywny charakter przekonań nauczycieli i brak zaangażowania w tworzenie „autonomicznego" środowiska edukacyjnego, które stają się źródłem ograniczeń autonomicznych praktyk studentów, wprowadzanych przez nauczyciela wątpiącego w sens rozwijania autonomii swoich podopiecznych. Istnieje bowiem obawa, że nauczyciele przejawiający rezygnację i swoisty cynizm wynikający z postrzegania uczniów jako osoby niezdolne do samodzielnego myślenia i działania, nie podejmują roli osoby uczącej się nowych edukacyjnych praktyk (teacher as innowator, learner in developing autonomy; Smith, 2003) oraz uczenia się sposobów rozwijania autonomii studentów (i swojej).

Opór wobec przekraczania granic dotychczasowych umiejętności i uczenia się uczestnictwa $\mathrm{w}$ autonomicznych praktykach edukacyjnych przejawiają także studenci. Podejmowanie zadań wymagających dekonstrukcji dotychczas znanych wzorów edukacyjnego działania i uczenia się autonomicznych praktyk edukacyjnych - wobec „zapośredniczeń" rodzinnej i szkolnej socjalizacji - sprawia wielu studentom poważne trudności, wymaga bowiem intelektualnej i emocjonalnej transgresji, gotowości do zmiany i odwagi jej wprowadzania.

Żadna ze stron nie wykazała się refleksyjnością dotyczącą ich osobowej odpowiedzialności czy gotowości podjęcia działań przekraczających doświadczane ograniczenia. Poza tym nauczyciele pokazali, że nie mają pomysłu na zmianę, są sfrustrowani, są czynnikiem stabilizacji systemu, nie angażują się zbytnio $\mathrm{w}$ doskonalenie procesu edukacyjnego, nie szukają możliwości spotkań, dialogu ze studentami. Wskazują, podobnie jak studenci „roszczeniowi”, przede wszystkim ograniczenia instytucjonalne, nie postrzegają siebie jako autonomicznego podmiotu, sprawcy niezależnego działania. $Z$ kolei studenci z jednej strony wyrażają roszczenia, z drugiej marzenia o autonomicznym studiowaniu, którego jednak nie podejmują, upatrując ograniczeń w pracy nauczycieli i organizacji procesu edukacyjnego. Dostosowują się (nawet studenci zaangażowani) do systemu, w którym podporządkowanie się nauczycielom jest gwarantem sukcesu na studiach. Realizują jednak swoje „autonomiczne” potrzeby w działaniach niejako poza systemem (wolontariat, koło naukowe). Sądzę zatem, że działania na rzecz tworzenia przestrzeni doświadczania autonomii w szkole wyższej są niezwykle ważne, a zwłaszcza te, które dotyczą przezwyciężania ograniczeń doświadczanych zarówno przez studentów, jak i nauczycieli. 


\section{Bibliografia}

Aviram, A. (2010). Navigating Through the Storm. Reinventing Education for Postmodern Democracies. Rotterdam: Sense Publishers.

Banasiak, B. (2008). I cóż po podmiocie w tak jałowym czasie? Forum Oświatowe, 20, 27-38.

Bauman, T. (2008). Uniwersytet jako balast dla ideologii rynkowej. W: B.D. Gołębniak (red.), Pytanie o szkotę wyższą. W trosce o człowieczeństwo (s. 116-131). Wrocław: Wydawnictwo Naukowe Dolnośląskiej Szkoły Wyższej.

Benson, P. (2008). Teachers' and learners' perspective on autonomy. W: T. Lamb, H. Reinders (red.), Learner and Teacher Autonomy. Concepts, realities, responses (s. 15-32). Amsterdam, Philadelphia: John Benjamin Publishing Company. DOI: https://doi.org/10.1075/aals.1.05ben.

Benson, P. (2013). Teaching and Researching Autonomy. New York: Routledge.

Benson, P., Voller, P. (2014). Autonomy and Independence in Language Learning. London: Routledge.

Beyers, W., Goossens, L., Vansant, I., Moors E. (2003). A Structural Model of Autonomy in Middle and Late Adolescence: Connectedness, Separation, Detachment, and Agency. Journal of Youth and Adolescence, 32 (5), 351-365.

Boykin McElhaney, K., Allen, J.P. (2001). Autonomy and Adolescent Social Functioning: The Moderating Effect and Risk. Child Development, 72 (1), 220-235. DOI: http://dx.doi.org/10.1111/14678624.00275 .

Bradbury, H. (red.) (2015). The SAGE Handbook of Action Research. Oregon University: Sage Publication.

Červinková, H., Gołębniak, B.D. (red.), (2010). Badania w działaniu. Pedagogika i antropologia zaangażowane. Wrocław: Wydawnictwo Naukowe Dolnośląskiej Szkoły Wyższej.

Červinková, H., Gołębniak, B.D. (red.) (2013). Edukacyjne badania w działaniu. Warszawa: Wydawnictwo Naukowe Scholar.

Christman, J., Anderson, J. (2005). Autonomy and the Challenges to Liberalism. Cambridge: Cambridge University Press.

Ciechanowska, D. (2015). The contemporary university as a threat to learner autonomy. W: K. Denek, A. Kamińska, P. Oleśniewicz (red.), Education of Tomorrow. Education and Other Forms of Activity of Adults (s. 65-78). Sosnowiec: Oficyna Wydawnicza „Humanitas”.

Colombo, M. (2003). Reflexivity and Narratives in Action Research: A Discursive Approach. Forum Qualitative Social Research, 4 (2). Pobrane z: http//www.Qualitative-research.net/fgs-texte/2-03/2-03colombo-e.htm (12.06.2006).

Czerepaniak-Walczak, M. (2001a). Badanie w działaniu - perspektywa akademicka. W: J. Krajewski, T. Lewowicki, J. Nikitorowicz (red.), Problemy współczesnej metodologii (s. 187-203). Olecko: Wszechnica Mazurska.

Czerepaniak-Walczak, M. (2001b). Badanie w działaniu akademickim; możliwości zastosowań w procesie podnoszenia jakości pracy uczelni. Rocznik Pedagogiczny, 24, 69-82.

Czerepaniak-Walczak, M. (2006). Pedagogika emancypacyjna. Rozwój świadomości krytycznej człowieka. Gdańsk: Gdańskie Wydawnictwo Psychologiczne.

Czerepaniak-Walczak, M. (2013). Autonomia w kolorze sepii w inkrustowanej ramie KRK. O procedurach i treściach zmiany w edukacji akademickiej. W: M. Czerepaniak-Walczak (red.), Fabryka 
dyplomów czy universitas? O „nadwiślańskiej” wersji przemian w edukacji akademickiej (s. 29-56). Kraków: Oficyna Wydawnicza Impuls.

Dam, L. (1995). Learner Autonomy 3: From Theory to Practice. Dublin: Authentik.

Dąbrowski, K. (1988). Pasja rozwoju. Warszawa: Almapress.

Dołęga, Z. (2000). Autonomia w okresie dorastania. Czasopismo Psychologiczne, 6 (1/2), 77-86.

Dykcik, W. (2009). Problemy autonomii i integracji społecznej osób niepełnosprawnych w środowisku życia. W: W. Dykcik (red.), Pedagogika specjalna (s. 315-336). Poznań: Wydawnictwo UAM.

Feldman, A. (2001). Teacher Development and Action Research: Findings from Six Years of Action Research in Schools. Pobrane z: http://www.unix.oit.umass.edu/ afeldman/ActionResearchPapers/ Feldmanetall2001.pdf (15.11.2006).

Gezerlis, A. (2001). Castoriadis and the Project of Autonomy. A Review of The Imaginary Institution of Society. Democracy and Nature, 7 (3), 469-487. DOI: https://doi.org/10.1080/10855660120092320.

Gołębniak, B.D. (red.) (2008a). Pytanie o szkołe wyższą. W trosce o człowieczeństwo. Wrocław: Wydawnictwo Naukowe Dolnośląskiej Szkoły Wyższej.

Gołębniak, B.D. (2008b). Wyjść poza scjentystyczne i personalistyczne myślenie o „uczeniu uczenia". W: E. Filipiak (red.), Rozwijanie zdolności uczenia się. Wybrane konteksty i problemy (s. 50-58). Bydgoszcz: Wydawnictwo Uniwersytetu im. Kazimierza Wielkiego.

Gołębniak, B.D. (2010). Poszukiwanie - refleksyjność - dialektyczne uczenie się. Nowe praktyki edukacyjne w szkole wyższej. W: J. Piekarski, D. Urbaniak-Zając (red.), Innowacje w edukacji akademickiej. Szkolnictwo wyższe w procesie zmiany (s. 255-268). Łódź: Wydawnictwo Uniwersytetu Łódzkiego.

Haworth, L. (1986). Autonomy. An Essay in Philosophical Psychology and Ethics. New Haven-London: Yale University Press.

Hmel, B.A., Pincus, A.L. (2002). The Meaning of Autonomy: On and Beyond the Interpersonal Circumplex. Journal of Personality, 70 (3), 277-310.

Holec, H. (1981). Autonomy and Foreign Language Learning. Oxford 1981: Pergamon Press.

Huang, J. (2006). Fostering learner autonomy within constraints: Negotiation and mediation in an atmosphere of collegiality. Prospect, 3 (21), 38-57.

Jasper, M.A. (2005). Using reflective writing within research. Journal of Research in Nursery, 3 (10), 247-260.

Kemmis, S., McTaggart, R. (2005). Participatory Action Research. Communicative Action and the Public Sphere. W: N.K. Denzin, Y.S. Lincoln (red.), The SAGE Handbook of Qualitative Research (s. 559-603). London-New Delhi: Sage Publications Inc., Thousand Oaks.

Koczanowicz, L. (2005). Wspólnota i emancypacje. Spór o społeczeństwo postkonwencjonalne. Wrocław: Wydawnictwo Naukowe Dolnośląskiej Szkoły Wyższej Edukacji TWP.

Kopka, J. (2008). Jednostka wobec moralności - subiektywna wizja przyszłości. W: J. Mariański, L. Smyczek (red.), Wartości, postawy i więzi moralne w zmieniającym się społeczeństwie (s. 57-75). Kraków: Wydawnictwo WAM.

Kozielecki, J. (2001). Psychotransgresjonizm. Nowy kierunek psychologii. Warszawa: Wydawnictwo Akademickie Żak. 
Kruszelnicki, M. (2008). Po humanizmie. Miraże podmiotowości (zarys problematyki). Forum Oświatowe, 20, 15-26.

Kwieciński, Z. (2014). Edukacja demokratyczna i humanistyczna jako ruch i dzieło społeczne. Toruń-Wrocław: sumptem autora.

Labouvie-Vief, G. (1982). Dynamic Development and Mature Autonomy, A Theoretical Prologue. Human Development, 25, 161-191.

Little, D. (1991). Learner Autonomy 1: Definitions, Issues and Problems. Dublin: Authentik.

Little, D., Ridley, J., Ushioda, E. (red.) (2003). Learner Autonomy in the Foreign Language Classroom: Teacher, Learner, Curriculum and Assessment. Dublin: Authentik.

Lynch, M.F., Vansteenkiste, M., Deci, E.L., Ryan, R.M. (2011). Autonomy as Process and Outcome: Revisiting Cultural and Practical Issues in Motivation for Counselling. The Counseling Psychologist, 39 (2), 286-302. DOI: 10.1177/0011000010388424.

Łapiński, B. (1988). Rola rodziny w osiąganiu autonomii przez dziecko w okresie dorastania. Psychologia Wychowawcza, 31 (5), 499-507.

Melosik, Z. (2008). Uniwersytet i komercjalizacja. Rekonstrukcja debaty. W: B.D. Gołębniak (red.), Pytanie o szkołe wyższą. W trosce o człowieczeństwo (s. 105-115). Wrocław: Wydawnictwo Naukowe Dolnośląskiej Szkoły Wyższej.

Melosik, Z. (2013). Kultura popularna i tożsamość młodzieży. W niewoli władzy i wolności. Kraków: Impuls.

Męczkowska, A. (2006). Podmiot i pedagogika: Od oświeceniowej utopii ku pokrytycznej dekonstrukcji. Wrocław: Wydawnictwo Naukowe Dolnośląskiej Szkoły Wyższej Edukacji TWP.

Mill, J.S. (1959). O wolności. W: J.S. Mill, Utylitaryzm. O wolności (s. 91-228). Warszawa: PWN.

Nussbaum, M.C. (2008a). Kształcenie dla zysku, kształcenie dla wolności. W: B.D. Gołębniak (red.), Pytanie o szkołe wyższa. W trosce o człowieczeństwo (s. 65-89). Wrocław: Wydawnictwo Naukowe Dolnośląskiej Szkoły Wyższej.

Nussbaum, M.C. (2008b). W trosce o człowieczeństwo. Klasyczna obrona reformy kształcenia ogólnego. Wrocław: Wydawnictwo Naukowe Dolnośląskiej Szkoły Wyższej.

Obuchowski, K. (2000). Człowiek intencjonalny, czyli o tym jak być sobą. Poznań: Dom Wydawniczy Rebis.

Obuchowski, K. (2006). The Revolutions of the Subjects. Łódź: Wydawnictwo Wyższej Szkoły Humanistyczno-Ekonomicznej.

Palfreyman, D., Smith, R.C. (red.) (2003). Learner Autonomy Across Cultures. Language Education Perspectives. New York: Palgrave Macmillan.

Perkowski, M. (2001). Samostanowienie narodów w prawie międzynarodowym. Warszawa: Wydawnictwa Prawnicze PWN.

Pestalozzi, J.H. (1972). Pisma pedagogiczne. Wrocław: Ossolineum.

Pieniążek, P. (2008). Podmiot (w) nowoczesności. Forum Oświatowe, 20, 39-50.

Potulicka, E., Rutkowiak, J. (2012). Neoliberalne uwikłania edukacji. Kraków: Oficyna Wydawnicza Impuls.

Reason, P., Bradbury, H. (2005). Introduction: Inquiry and Participation in Search of a World Worthy of Human Aspiration. W: P. Reason, H. Bradbury (red.), Handbook of Action Research: Participative Inquiry and Practice (s. 1-14). London: Thousand Oaks, New Delhi: Sage Publications. 
Reason, P., Torbet, W.R. (2010). Zwrot działaniowy. Ku transformacyjnej nauce społecznej. W: H. Červinková, B.D. Gołębniak (red.), Badania w działaniu. Pedagogika i antropologia zaangażowane (s. 136-150). Wrocław: Wydawnictwo Naukowe Dolnośląskiej Szkoły Wyższej.

Rogers, C. (2002). O stawaniu się osobą. Poznań: Dom Wydawniczy Rebis.

Ryan, R.M., Deci, E.L. (2006). Self-Regulation and the Problem of Human Autonomy: Does Psychology Need Choice, Self-Determination, and Will? Journal of Personality, 74 (6), 1557-1585.

Smith, R.C. (2003). Teacher education for teacher - learner autonomy. Pobrane z: http:// www.Warwick. ac.uk/ẽlsdr/Teacher_autonomy.pdf(10.01.2006).

Speck, O. (2005). Być nauczycielem. Trudności wychowawcze w czasie zmian społeczno-kulturowych. Gdańsk: Gdańskie Wydawnictwo Psychologiczne.

Susman, G.I., Evered, R.E. (2010). Ocena naukowych walorów badań w działaniu. W: H. Červinková, B.D. Gołębniak (red.), Badania w działaniu. Pedagogika $i$ antropologia zaangażowane (s. 89-115). Wrocław: Wydawnictwo Naukowe Dolnośląskiej Szkoły Wyższej.

Szostek, A. (2017). Autonomia uczelni a odpowiedzialność wobec społeczeństwa. W: Autonomia uczelni i środowiska akademickiego - odpowiedzialność i etos akademicki (s. 21-27). Warszawa: Instytut Problemów Współczesnej Cywilizacji im. Marka Dietricha.

Sztompka, P. (2017). Autonomia - fundament kultury akademickiej. W: Autonomia uczelni i środowiska akademickiego - odpowiedzialność i etos akademicki (s. 29-34). Warszawa: Instytut Problemów Współczesnej Cywilizacji im. Marka Dietricha.

Thanasoulas, D. (2006). What is Learner Autonomy and How Can It Be Fostered. Pobrane z: http://iteslj. org/Articles?Thanasoulas.html (15.10.2006).

Wołodźko, E. (2013). Ku autonomii studiowania. Procesy, znaczenia, kontekst, zmiana. Olsztyn: Wydawnictwo Uniwersytetu Warmińsko-Mazurskiego.

\section{Streszczenie}

Artykuł przedstawia badania ograniczeń autonomii, postrzeganych przez studentów i nauczycieli akademickich, które zrealizowano $\mathrm{z}$ zastosowaniem refleksyjnych technik badawczych (reflective writing i otwartych wywiadów pogłębionych). Uzyskane dane wykazały, że badani sytuują ograniczenia autonomii w partnerach procesu edukacyjnego - nauczyciele w braku kompetencji studentów, studenci w braku możliwości dialogu oraz konieczności podporządkowania się nauczycielom, a także w niesprzyjającej ich potrzebom organizacji procesu edukacyjnego oraz dysfunkcyjnym $\mathrm{w}$ ich ocenie systemie edukacyjnym. Żadna ze stron nie wykazała się refleksyjnością dotyczącą ich osobowej odpowiedzialności czy gotowości podjęcia działań przekraczających doświadczane ograniczenia. Wobec braku zaangażowania nauczycieli w budowanie środowiska edukacyjnego wspierającego autonomię, studenci, zwłaszcza ci najaktywniejsi, poszukują pól autonomicznego działania w kołach naukowych, wolontariacie, samorządzie. Badania wykazały potrzebę tworzenia przestrzeni doświadczania autonomii w szkole wyższej, sprzyjającej rozwojowi podmiotowej świadomości zarówno nauczycieli akademickich, jak i studentów.

Słowa kluczowe: autonomia, ograniczenia autonomii, edukacja wyższa 


\section{AUTONOMY IN AN ACADEMIC SPACE-MEANINGS, EXPERIENCES, CONSTRAINTS}

\section{Summary}

The article presents a research concerning the constraints of autonomy, perceived by students and academic teachers. The reflective inquiry techniques (reflective writing, open in-depth interviews) were applicated. Data proved that both students and teachers located the investigated constraints within the partners of educational process - teachers in a lack of students' competences; students in a lack of possibility to dialog and a necessity of subordination to teachers. As the barriers of autonomy students also indicated unfavorable to their needs educational process' organization and dysfunctional, in their opinions, educational system. None of the research participants revealed reflectivity concerning their personal responsibility or readiness to take any actions to overcome the constraints they experienced. In the absence of any teachers' engagement in autonomy supportive environment's creation, the students, especially the most active ones, searched for some possibilities of autonomous activities in other areas, like students scientific circles, volunteering and students council. The research - although conducted in a small group of subjects - indicated a need to create a space for autonomous experiences in higher education which favor students' and teachers' consciousness of being autonomous subjects in education.

Keywords: autonomy, the constraints of autonomy, higher education 